\title{
Hydrochemical study of water collected at a section of the Lower Volta River (Akuse to Sogakope area), Ghana
}

\author{
E. K. Gampson • V. K. Nartey • \\ A. A. Golow $\cdot$ T. T. Akiti
}

Received: 17 July 2013/Accepted: 24 October 2013/Published online: 7 November 2013

(c) The Author(s) 2013. This article is published with open access at Springerlink.com

\begin{abstract}
The present hydrochemical study at the Lower Volta River (Akuse to Sogakope area), Ghana was conducted by determining the physico-chemical parameters $(\mathrm{pH}$, temperature, total dissolved solute, electrical conductivity, total hardness, phosphate $\left(\mathrm{PO}_{4}{ }^{3-}\right)$, nitrate $\left(\mathrm{NO}_{3}{ }^{-}\right)$, sulfate $\left(\mathrm{SO}_{4}{ }^{2-}\right)$, dissolve oxygen (DO), biological oxygen demand, calcium $\left(\mathrm{Ca}^{2+}\right)$, sodium $\left(\mathrm{Na}^{+}\right)$, magnesium $\left(\mathrm{Mg}^{2+}\right)$, total iron $(\mathrm{Fe})$, manganese $(\mathrm{Mn})$, copper $(\mathrm{Cu})$ nickel $(\mathrm{Ni})$, and total chromium $(\mathrm{Cr})$ at 38 sampling sites during the wet and the dry seasons. The physical and ionic parameters were mostly found within the WHO (Guidelines for drinking-water quality, 3rd edn, Geneva 2004) standard for drinking water. The trace metals except $\mathrm{Cu}$ at some sites recorded values above the WHO (Guidelines for drinking-water quality, 3rd edn, Geneva 2004) standard for drinking water. This shows that the river water is not entirely fit for drinking. Mean values of physico-chemical parameters were mostly found to be high in the dry season as compared to the wet season. Cluster analysis (CA) and principal component analysis (PCA) were employed to evaluate the water quality and the interrelationship between variables. CA grouped the physico-chemical parameters into three groups (physical/minor ions, major ions and trace
\end{abstract}

E. K. Gampson ( $\square)$

Ghana Atomic Energy Commission, Kwabenya,

P.O. Box LG 80, Legon-Accra, Ghana

e-mail: e.gampson@gaecgh.org

V. K. Nartey

Department of Chemistry, University of Ghana,

P. O. Box LG 56, Legon-Accra, Ghana

A. A. Golow - T. T. Akiti

Graduate School of Nuclear and Allied Sciences,

University of Ghana, P.O. Box LG 80, Accra, Ghana elements). Correlation analysis showed that physicochemical parameters do not vary much in terms of the sampling sites. Thus, based on obtained information, it is possible to design a future, desirable sampling strategy, which could reduce the number of sampling stations and associated costs for effective river water quality management. Results showed that four principal components (industrial effect, domestic factor, natural source and agricultural effect) accounted for $65.59 \%$ of the total variance among the water quality parameters. PCA also identified sampling sites 69R, 63R, 51M, 87L, 35L, 74L and $84 \mathrm{~L}$ as polluted with metals. Therefore, water quality monitoring and control of release of industrial and anthropogenic wastes into the river are strongly needed.

Keywords Lower Volta River · Physico-chemical parameters $\cdot$ Multivariate analysis $\cdot$ Akuse $\cdot$ Sogakope

\section{Introduction}

Water is extremely essential for survival of all living organisms. The quality of water is vital concern for mankind since it is directly linked with human welfare. The natural processes, such as precipitation inputs, erosion, weathering, as well as the anthropogenic influences, via, domestic, industrial, fishing and agricultural activities, calling for increasing exploitation of water resources, together determine the quality of surface water in an area. Rivers play a major role in assimilation or carrying off of municipal and industrial wastewater and runoff from agricultural land, the former constitutes the constant polluting source, whereas the latter is a seasonal phenomenon. An investigation through major towns in the study area revealed that the major water sources for most activities are 
the untreated water from the Volta River, accounting for about $37 \%$ of the entire water sources used (Amoah and Koranteng 2006). This water source is the alternative to the inconsistent flow of pipe-borne water supply, which would have been more reliable source of safe water for the growing population. United Nations Economic and Social Commission for Asia and the Pacific (UNESCAP 2000) revealed that 15 out of every 1,000 children born in the developing world die before the age of five from diarrhea caused by drinking polluted water. Hence, constant monitoring of river water quality in the area (Akuse to Sogakope) is needed so as to record any alteration in the quality, which may lead to outbreak of health disorder or serious health effect. Also, the river water quality changes with time and space, and continuous water quality measurements and analyses are necessary for effective water quality management in the study area.

The application of different multivariate statistical techniques, such as cluster analysis (CA), principal component analysis (PCA) and factor analysis (FA), helps in the interpretation of complex data matrices to better understand the water quality, river health monitoring and assessment, ecological status of the studied systems, allows the identification of possible factors/sources that influence water systems and offers a valuable tool for reliable management of water resources as well as rapid solution to pollution problems (Vega et al. 1998; Lee et al. 2001; Adams et al. 2001; Wunderlin et al. 2001; Reghunath et al. 2002; Simeonova et al. 2003, Simeonov et al. 2003; Pinto and Maheshwari 2011; Pinto et al. 2012). Multivariate statistical techniques have been applied to characterize and examine surface and freshwater quality, and it is useful in verifying temporal and spatial variations caused by natural and anthropogenic factors. (Helena et al. 2000; Singh et al. 2004, 2005). The objectives of this study were to determine the physico-chemical properties, dissolved trace metals, to understand the interrelationships between different variables and assess the pollution status.

\section{Study area}

The study area spans from the Akuse part of the Volta River which is in the Lower Manya Krobo district and is between latitude $6^{\circ} 05^{\prime} \mathrm{S}, 6^{\circ} 30^{\prime} \mathrm{N}$ and longitude $0^{\circ} 08^{\prime} \mathrm{E}$, $0^{\circ} 20^{\prime} \mathrm{W}$ to Sogakope which lies in the South Tongu district and is between latitudes $6^{\circ} 10^{\prime} \mathrm{N}, 5^{\circ} 45^{\prime} \mathrm{N}$ and longitudes $30^{\circ} 30^{\prime} \mathrm{W}, 0^{\circ} 45^{\prime} \mathrm{W}$ (Fig. 1). The vegetation around the catchment area is moist semi-deciduous forest, wooded savanna and open grassland with a mean annual rainfall ranging between 195 and $1,500 \mathrm{~mm}$. The average relative humidity is high during the wet season, between 70 and $80 \%$, and low in the dry season with about 55-60\%. The minimum to maximum temperature in the study area ranges from 22 to $30^{\circ} \mathrm{C}$, respectively. The area experiences two major seasons, namely wet and dry seasons. The rainy season exhibits double maxima: the main rainy season occurs between April and July, while the minor one falls between September and October of every year. The dry and warm season is experienced from November to March. The underlying rocks in the study area are metamorphic in origin and mainly consist of gneiss and schist. The major soils formed over these geological formations include $\mathrm{Zi}$ wai-Zebe complex, Tondo-Motawme complex and Agawtaw-Pejeglo complex soils which are formed over the Dahomeyan acidic gneiss rocks. Toje-Agawtaw association and Amo-Tefle association soils have the acidic gneiss and schist as their parent rocks. Ada-Oyibi association, Ada association, Aveyime-Ada association and Oyibi-Muni association soils have alluvial and coastal deposits as their parent rock (Ministry of Local Government and Rural Development, Ghana, 2010).

\section{Materials and methods}

Thirty-eight surface water were sampled at different sites on the Lower Volta River (Akuse to the Sogakope area, Ghana) in July, 2011 in the wet season and February, 2012 in the dry season, using pre-washed polythene containers. Locations of selected sampling sites were determined using the Garmin Vista CP GPS (Fig. 1). pH, temperature (Temp), electrical conductivity (EC), total dissolved solute (TDS) and dissolved oxygen (DO) were determined in the field. The $\mathrm{pH}$ and temperature were determined using a (Ecoscan Ion 5) $\mathrm{pH}$ meter. EC and TDS were determined using a Specific conductance meter (HACH SensIon5). The DO was determined using the Winkler's Method (APHA 1998). Phosphate was determined by the Vanadate-molybdate method, sulfate by turbidimetric method and nitrate by UV spectrophotometric method (APHA 1998). Total hardness (TH) was estimated by the complexometric titration with standard EDTA solution using Eriochrome BlackT as indicator. Samples for biological oxygen demand (BOD) were incubated in the laboratory for 5 days at $20^{\circ} \mathrm{C}$ and determined by the Winkler's Method (APHA 1998).

In the laboratory, the dissolved trace metal concentrations in the water samples were determined for $\mathrm{Ni}$, total $\mathrm{Cr}$, $\mathrm{Mn}, \mathrm{Cu}$ and total $\mathrm{Fe}$ by direct flame Atomic Absorption Spectrometry (AAS), Eaton et al. (2005). A $6 \mathrm{~mL}$ of $65 \%$ $\mathrm{HNO}_{3}, 3 \mathrm{~mL}$ of $35 \% \mathrm{HCl}$, and $0.25 \mathrm{~mL}$ of $\mathrm{H}_{2} \mathrm{O}_{2}$ were added to $5 \mathrm{~mL}$ of water samples in Teflon beaker. The resulting solutions were put into Ethos 900 Microwave for $30 \mathrm{~min}$ at $250 \mathrm{~W}$ power for digestion. The digested solutions were topped to $20 \mathrm{~mL}$ by adding de-ionized distilled water. The solutions were thoroughly mixed and aspirated 
The $R, M$ and $L$ inserted in the location map represent the RIGHT, MIDDLE and LEFT portion of the river.

The numbers attached to $R, M$ and $L$ represents the elevation above mean sea level.

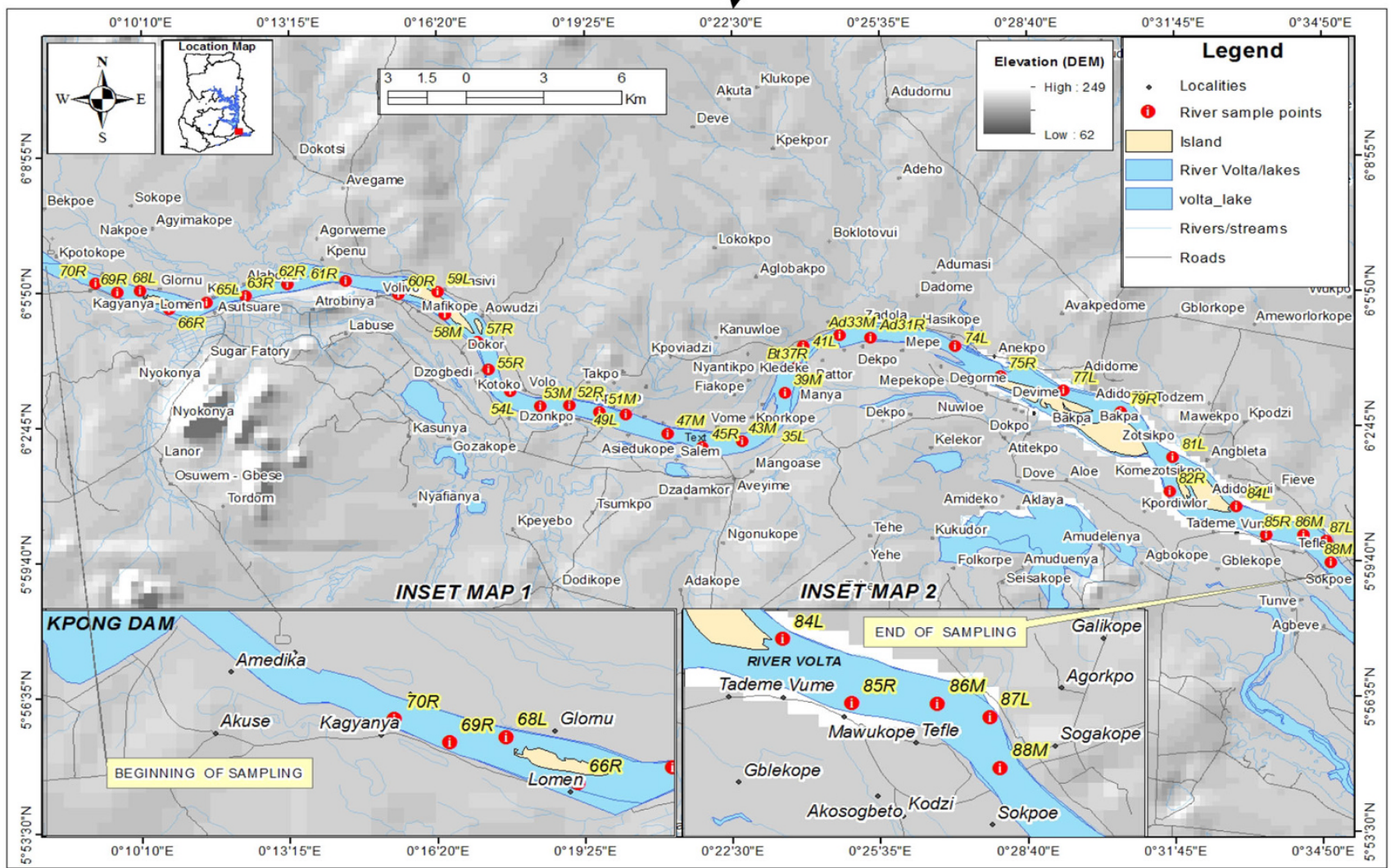

Fig. 1 Location map of the study area

into the spectrometer (Varian AA240 fast sequential atomic absorption spectrometer) following specifications outlined for each element in the cook book of AAS (APHA 1998).
$\mathrm{Ca}, \mathrm{Na}$ and $\mathrm{Mg}$ were determined by Instrumental Neutron Activation Analysis (INAA). A $0.5 \mathrm{~mL}$ volume of sample was transferred with calibrated Eppendorf tip ejector pipette into pre-weighed $1.5 \mathrm{~mL}$ polyethylene vials 
with a piece of cotton, capped and heat-sealed to obtain a mass of $500 \mathrm{mg}$. The cotton wool was added as a safety measure to avoid the sample spilling and spreading radioactivity in case the vial opens in the reactor or while coming out of the reactor. Irradiations were performed using the Ghana Research Reactor-1 (GHARR-1) facility at Ghana Atomic Energy Commission, Kwabenya.

\section{Cluster analysis}

Cluster analysis is a group of multivariate techniques whose primary purpose is to assemble objects based on the characteristics they possess. Cluster analysis classifies objects, so that each object is similar to the others in the cluster with respect to a predetermined selection criterion. The resulting clusters of objects should then exhibit high internal (within-cluster) homogeneity and high external (between-cluster) heterogeneity. Hierarchical clustering is the most common approach, which provides intuitive similarity relationships between any one sample and the entire data set, and is typically illustrated by a dendrogram (tree diagram) (McKenna 2003). The dendrogram provides a visual summary of the clustering processes, presenting a picture of the groups and their proximity, with a dramatic reduction in dimensionality of the original data. The Euclidean distance usually gives the similarity between two samples and a distance can be represented by the difference between analytical values from the samples (Otto 1998). A classification scheme using the Euclidean distance for similarity measures and the between-groups linkage method was performed on the normalized data to produce the most distinctive classification where each member within a group is more similar to its fellow members than to any member outside of the group (Guler and Thyne 2004).

\section{PCA/FA}

PCA is designed to transform the original variables into new, uncorrelated variables (axes), called the principal components, which are linear combinations of the original variables. The new axes lie along the directions of maximum variance (Shrestha and Kazama 2007). PCA can be expressed as:

$Z_{i j}=a_{i 1} x_{1 j}+a_{i 2} x_{2 j}+a_{i 3} x_{3 j}+\cdots+a_{i m} x_{m j}$

where $Z$ is the component score, $a$ is the component loading, $x$ is the measured value of variable, $i$ is the component number, $j$ is the sample number and $\mathrm{m}$ is the total number of variables.

PCA of the normalized variables was performed to extract significant PCs and to further reduce the contribution of variables with minor significance. These PCs were subjected to varimax rotation (Brumelis et al. 2000; Singh et al. 2004, 2005; Abdul-Wahab et al. 2005). As a result, a small number of factors will usually account for approximately the same amount of information as does the much larger set of original observations. The FA can be expressed as:

$Z_{i j}=a_{f 1} x_{1 i}+a_{f 2} x_{2 i}+a_{f 3} x_{3 i}+\cdots+a_{f m} x_{m i}+e_{f i}$

where $Z$ is the measured variable, $a$ is the factor loading, $f$ is the factor score, $e$ is the residual term accounting for errors or other source of variation, $i$ is the sample number and $\mathrm{m}$ is the total number of factors.

The results of the AAS, INAA and UV visible spectrophotometry of standard reference materials of reported values of the ionic and elemental compositions were compared with those of the local laboratory. The precision of the parameters analyzed was calculated as percentage relative standard deviation (\% RSD) of six replicate measurements and was found to be within $10 \%$.

\section{Results and discussion}

$\mathrm{pH}$ and temperature

The $\mathrm{pH}$ values which measure as to how acidic or basic water is, ranged from 6.45 to 7.25 with a mean value of 6.89 in the wet season (Table 1; Fig. 2). The dry season ranged from 6.59 to 7.26 with a mean value of 6.91 (Table 2; Fig. 2). These could be described as moderately acidic to neutral waters. Similarly, this phenomenon was observed by Amoah and Koranteng (2006). There was an exception at site $65 \mathrm{~L}$ in the wet season which had a $\mathrm{pH}$ value of 6.45 . The slightly lower $\mathrm{pH}$ value of this water sample could be due to photosynthetic activity and microbial respiration as well as decomposing activities at the site affecting the $\mathrm{pH}$ value. The mean value of $\mathrm{pH}$ (6.89) in the wet season was slightly lower than that of the mean $\mathrm{pH}$ (6.91) value in the dry season. This may be due to the fact that rainfall causes the dilution of acid and metals concurrently into the water, which can have an immediate or a long-term effect by influencing the chemical composition and $\mathrm{pH}$ fluctuations of the water (Preda and Cox 2000; Abubacker et al. 1996). The pH values of all the sampling sites except 65L (Table 1) fell within the range of 6.5-8.5, set by the WHO (2004) standard for drinking water. This shows that the surface water in the area is safe for agricultural, recreational and domestic uses based on the $\mathrm{pH}$ values. Water temperature also ranged from 26.5 to $30.2^{\circ} \mathrm{C}$ and 27.5 to $30.9{ }^{\circ} \mathrm{C}$ with mean values of 28.9 and $29.43{ }^{\circ} \mathrm{C}$ in the wet and dry seasons, respectively (Tables 1, 2; Fig. 2). Overall, the temperatures of all the sampling sites were relatively constant and almost within 
Table 1 Statistical summary of physico-chemical parameters determined at 38 sampling sites $(N=38)$ in the wet season

\begin{tabular}{llllllll}
\hline Parameter & Unit & $N$ & Min. & Max. & Mean & SD & $\begin{array}{l}\text { WHO (2004) } \\
\text { Std }\end{array}$ \\
\hline $\mathrm{pH}$ & & 38 & 6.45 & 7.25 & 6.89 & 0.19 & $6.5-8.5$ \\
$\mathrm{Temp}$ & ${ }^{\circ} \mathrm{C}$ & 38 & 26.5 & 30.2 & 28.9 & 0.19 & - \\
$\mathrm{EC}$ & $\mu \mathrm{S} / \mathrm{cm}$ & 38 & 61.7 & 82.2 & 69.76 & 5.23 & 1,400 \\
$\mathrm{TDS}$ & $\mathrm{mg} / \mathrm{L}$ & 38 & 29.7 & 39.1 & 33.28 & 2.11 & 500 \\
$\mathrm{DO}$ & $\mathrm{mg} / \mathrm{L}$ & 38 & 0.63 & 2.28 & 1.1 & 0.43 & - \\
$\mathrm{TH}$ & $\mathrm{mg} / \mathrm{L}$ & 38 & 36 & 108 & 54.32 & 13.1 & 130 \\
$\mathrm{BOD}$ & $\mathrm{mg} / \mathrm{L}$ & 38 & 0.04 & 0.47 & 0.22 & 0.07 & $0.8-5.0$ \\
$\mathrm{Mg}^{2+}$ & $\mathrm{mg} / \mathrm{L}$ & 38 & 2.92 & 23.33 & 9.67 & 3.38 & 50 \\
$\mathrm{Na}^{+}$ & $\mathrm{mg} / \mathrm{L}$ & 38 & 7.8 & 11.0 & 8.53 & 0.61 & 200 \\
$\mathrm{Ca}^{2+}$ & $\mathrm{mg} / \mathrm{L}$ & 38 & 3.2 & 12.8 & 5.55 & 1.85 & 100 \\
$\mathrm{NO}_{3}{ }^{-}$ & $\mathrm{mg} / \mathrm{L}$ & 38 & 1.0 & 24.77 & 11.58 & 8.16 & 50 \\
$\mathrm{SO}_{4}{ }^{2-}$ & $\mathrm{mg} / \mathrm{L}$ & 38 & 6.89 & 28.11 & 16.97 & 6.43 & 250 \\
$\mathrm{PO}_{4}{ }^{3-}$ & $\mathrm{mg} / \mathrm{L}$ & 38 & 1.33 & 10.67 & 4.73 & 2.67 & - \\
$\mathrm{Fe}$ & $\mathrm{mg} / \mathrm{L}$ & 38 & 0.032 & 0.344 & 0.091 & 0.106 & 0.300 \\
$\mathrm{Mn}$ & $\mathrm{mg} / \mathrm{L}$ & 38 & 0.012 & 0.272 & 0.080 & 0.071 & 0.100 \\
$\mathrm{Cu}^{2}$ & $\mathrm{mg} / \mathrm{L}$ & 38 & 0.016 & 0.084 & 0.024 & 0.022 & 2 \\
$\mathrm{Ni}^{2}$ & $\mathrm{mg} / \mathrm{L}$ & 38 & 0.020 & 0.160 & 0.079 & 0.039 & 0.02 \\
$\mathrm{Cr}$ & $\mathrm{mg} / \mathrm{L}$ & 38 & 0.012 & 0.096 & 0.041 & 0.025 & 0.05 \\
\hline
\end{tabular}

$N$ total number of data points, WHO Std World Health Organization standards, Std.Dev standard deviation

the range $\left(27.0-30{ }^{\circ} \mathrm{C}\right)$ reported by Amoah and Koranteng (2006).

Electrical conductivity and Total dissolved solute

The electrical conductivity (EC) which is a measure of water capacity to convey electric current, varied from 61.7 to 82.2 and 62.5 to $836 \mu \mathrm{S} / \mathrm{cm}$ with mean values of 69.76 and $71.01 \mu \mathrm{S} / \mathrm{cm}$ in the wet and dry seasons, respectively
(Tables 1, 2; Fig. 2). This is below the range (99-207 $\mu \mathrm{S} /$ $\mathrm{cm})$ reported by Amoah and Koranteng (2006). The lower EC in the study area indicates the low enrichment of salts in the surface water. The value of electrical conductivity may be an approximate index of the total content of dissolved substance in water and depends upon temperature, concentration and types of ions present (Hem 1985). Ionic pollutants from anthropogenic sources and soluble minerals from bedrock (Kney and Brandes 2007) contributed to the EC in the study area. The EC can be classified as type I, if the enrichments of salts are low $(\mathrm{EC}<1,500 \mu \mathrm{S} / \mathrm{cm})$; type II, if the enrichment of salts are medium (EC 1,500 and $3,000 \mu \mathrm{S} / \mathrm{cm}$ ); and type III, if the enrichments of salts are high (EC $>3,000 \mu \mathrm{S} / \mathrm{cm})$. According to the above classification of EC, all the surface water samples came under the type I (low enrichment of salts). The EC values were below the $1,400 \mu \mathrm{S} / \mathrm{cm}$ set by WHO (2004) standard for drinking water. Total dissolved solute TDS, is a measure of the total ions in solution and values were found ranging from 29.7 to $39.1 \mathrm{mg} / \mathrm{L}$ with a mean value of $33.8 \mathrm{mg} / \mathrm{L}$ in the wet season (Table 1; Fig. 2). The dry season varied from 29.7 to 39.4 with a mean value of 33.83 (Table 2; Fig. 2). Davis and De Wiest (1966) classified TDS in water as follows: desirable for drinking $(<500 \mathrm{mg} / \mathrm{L})$ and permissible for drinking $(500-1,000 \mathrm{mg} / \mathrm{L})$. According to the above criteria, all the water samples were found desirable for drinking. Also, the water will be safe for drinking according to the WHO (2004) standard. TDS concentrations in natural waters are the result of weathering and dissolution of minerals from local soil and bedrock (Freeze and Cherry 1979; Peters 1984; Kney and Brandes 2007). Primary sources for TDS in receiving waters are agricultural runoff, leaching of soil contaminant and point source water pollution discharged from industrial or sewage treatment plants.
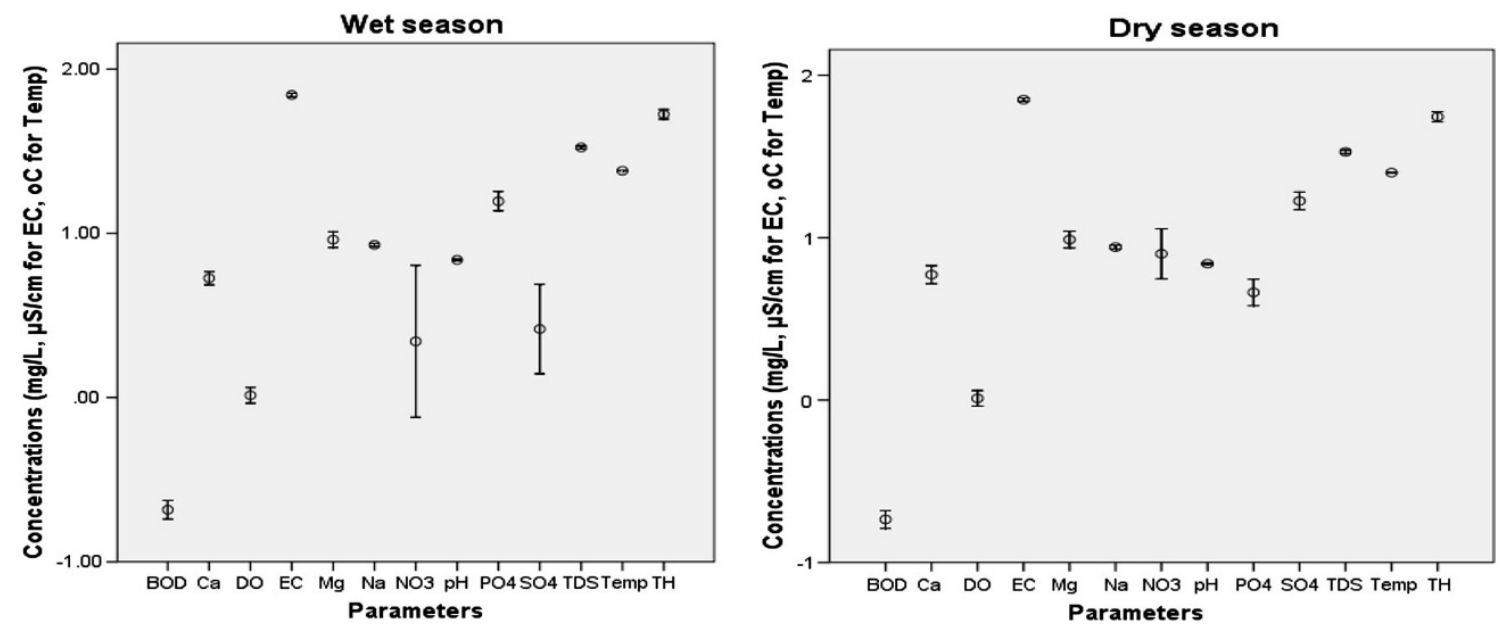

Fig. 2 Standard error bars presenting statistical summaries of the physical/ionic data for both seasons 
Dissolved oxygen and Biological oxygen demand

Dissolved oxygen (DO) varied from 0.63 to 2.28 and 0.63 to $2.29 \mathrm{mg} / \mathrm{L}$ with mean values of 1.10 and $1.09 \mathrm{mg} / \mathrm{L}$ in the wet season and dry season, respectively (Tables 1,2 ; Fig. 2). The highest value was measured during the wet season at sampling site $35 \mathrm{~L}(2.29 \mathrm{mg} / \mathrm{L})$ and the lowest value was measured at site $57 \mathrm{R}(0.63 \mathrm{mg} / \mathrm{L})$ in the dry season. The major factor controlling dissolved oxygen concentration is biological activity; thus for example, photosynthesis producing oxygen while respiration and nitrification consume oxygen (although under hypoxic or anoxic conditions, denitrification can be a source of oxygen) (Best et al. 2007). The water lacked aquatic plants which produced oxygen through respiration as well as having decomposing activities of organic compounds by aerobic organisms which consumed oxygen (Best et al. 2007), thus resulting in low DO. Also, with the progress of the dry season, dissolved oxygen decreased probably due to increase in temperature and also due to increased microbial activity (Moss 1972; Morrissette and Mavinic, 1978; Sangu and Sharma 1987 and Kataria et al. 1996). Biological oxygen demand concentrations determined in the water samples for both wet season (mean value of $0.22 \mathrm{mg} / \mathrm{L}$ ) and dry seasons (mean value of $0.19 \mathrm{mg} / \mathrm{L}$ ) were far below the $0.8-5 \mathrm{mg} / \mathrm{L}$, set by WHO (2004) standards for drinking water, ranging from 0.04 to 0.47 and 0.05 to $0.35 \mathrm{mg} / \mathrm{L}$ in

Table 2 Statistical summary of physico-chemical parameters determined at 38 sampling sites $(N=38)$ in the dry season

\begin{tabular}{|c|c|c|c|c|c|c|c|}
\hline Parameter & Unit & $\mathrm{N}$ & Min. & Max. & Mean & SD & $\begin{array}{l}\text { WHO (2004) } \\
\text { Std }\end{array}$ \\
\hline $\mathrm{pH}$ & & 38 & 6.59 & 7.26 & 6.91 & 0.19 & $6.5-8.5$ \\
\hline Temp & ${ }^{\circ} \mathrm{C}$ & 38 & 27.5 & 30.9 & 29.43 & 0.11 & - \\
\hline $\mathrm{EC}$ & $\mu \mathrm{S} / \mathrm{cm}$ & 38 & 62.5 & 83.6 & 71.01 & 5.50 & 1,400 \\
\hline TDS & $\mathrm{mg} / \mathrm{L}$ & 38 & 29.7 & 39.4 & 33.83 & 2.39 & 500 \\
\hline DO & $\mathrm{mg} / \mathrm{L}$ & 38 & 0.63 & 2.29 & 1.09 & 0.44 & - \\
\hline $\mathrm{TH}$ & $\mathrm{mg} / \mathrm{L}$ & 38 & 36 & 108 & 56.94 & 13.74 & 130 \\
\hline BOD & $\mathrm{mg} / \mathrm{L}$ & 38 & 0.05 & 0.35 & 0.19 & 0.07 & $0.8-5.0$ \\
\hline $\mathrm{Mg}^{2+}$ & $\mathrm{mg} / \mathrm{L}$ & 38 & 2.92 & 23.33 & 10.33 & 3.57 & 50 \\
\hline $\mathrm{Na}^{+}$ & $\mathrm{mg} / \mathrm{L}$ & 38 & 7.9 & 11.0 & 8.77 & 0.76 & 200 \\
\hline $\mathrm{Ca}^{2+}$ & $\mathrm{mg} / \mathrm{L}$ & 38 & 3.2 & 14.4 & 6.40 & 2.76 & 100 \\
\hline $\mathrm{NO}_{3}^{-}$ & $\mathrm{mg} / \mathrm{L}$ & 38 & 1.11 & 24.89 & 11.89 & 9.33 & 50 \\
\hline $\mathrm{SO}_{4}{ }^{2-}$ & $\mathrm{mg} / \mathrm{L}$ & 38 & 6.56 & 28.11 & 18.0 & 6.26 & 250 \\
\hline $\mathrm{PO}_{4}{ }^{3-}$ & $\mathrm{mg} / \mathrm{L}$ & 38 & 1.44 & 11.67 & 5.23 & 3.2 & - \\
\hline $\mathrm{Fe}$ & $\mathrm{mg} / \mathrm{L}$ & 38 & 0.032 & 0.348 & 0.094 & 0.110 & 0.300 \\
\hline $\mathrm{Mn}$ & $\mathrm{mg} / \mathrm{L}$ & 38 & 0.012 & 0.278 & 0.081 & 0.071 & 0.100 \\
\hline $\mathrm{Cu}$ & $\mathrm{mg} / \mathrm{L}$ & 38 & 0.016 & 0.085 & 0.025 & 0.018 & 2 \\
\hline $\mathrm{Ni}$ & $\mathrm{mg} / \mathrm{L}$ & 38 & 0.020 & 0.162 & 0.080 & 0.046 & 0.02 \\
\hline $\mathrm{Cr}$ & $\mathrm{mg} / \mathrm{L}$ & 38 & 0.012 & 0.098 & 0.044 & 0.029 & 0.05 \\
\hline
\end{tabular}

$N$ total number of data points, WHO Std World Health Organization standards, Std.Dev standard deviation the wet season and dry season, respectively (Tables 1, 2; Fig. 2). The highest value was recorded at sampling site 49L $(0.47 \mathrm{mg} / \mathrm{L})$ and lowest at Bt37R $(0.04 \mathrm{mg} / \mathrm{L})$.

Total hardness

Total hardness (TH) ranged from 36 to $108 \mathrm{mg} / \mathrm{L}$ for both seasons with mean values of 54.32 and $56.94 \mathrm{mg} / \mathrm{L}$ in the wet and dry seasons, respectively (Tables 1, 2; Fig. 2). The highest values for both seasons were recorded at sites Bt37R, Ad31R, 45R, 68L, 88M, and 84L with values ranging from 72 to $108 \mathrm{mg} / \mathrm{L}$. "Soft" and "Hard" water have been associated with total hardness over the years and this has been classified by Durfor and Becker (1964) as follows: Soft $(0-60 \mathrm{mg} / \mathrm{L})$, Moderately hard $(61-120 \mathrm{mg} /$ L), Hard (121-180 mg/L) and above $180 \mathrm{mg} / \mathrm{L}$ as very hard. About $76 \%$ of the sampled water fell within the soft $(0-60 \mathrm{mg} / \mathrm{L})$ region; hence, the water in the study area could be said to be "Soft". The hardness of the water is due to the presence of ions such as calcium and magnesium.

Magnesium, sodium and calcium

Magnesium $\left(\mathrm{Mg}^{2+}\right)$ ranged from 2.92 to $23.33 \mathrm{mg} / \mathrm{L}$ for both seasons with mean values of 9.67 and $10.33 \mathrm{mg} / \mathrm{L}$ in the wet and dry seasons, respectively (Tables 1, 2; Fig. 2). Sodium is generally found in lower concentration than $\mathrm{Ca}^{2+}$ and $\mathrm{Mg}^{2+}$ in freshwater. The concentration of sodium $\left(\mathrm{Na}^{+}\right)$varied from 7.8 to 11.0 and 7.9 to $11.0 \mathrm{mg} /$ $\mathrm{L}$ with mean values of 1.10 and $1.09 \mathrm{mg} / \mathrm{L}$ in the wet season and dry season, respectively (Tables 1, 2; Fig. 2). Calcium $\left(\mathrm{Ca}^{2+}\right)$ concentrations also ranged from 3.2 to 12.8 and 3.2 to $14.4 \mathrm{mg} / \mathrm{L}$ with mean values of 5.56 and $6.40 \mathrm{mg} / \mathrm{L}$ for both wet and dry seasons, respectively (Tables 1, 2; Fig. 2). These salts could come from a tissue manufacturing factory located upstream which releases effluent containing bleaching powder into the Volta River. $\mathrm{Mg}^{2+}, \mathrm{Na}^{+}$and $\mathrm{Ca}^{2+}$ had their concentrations at all the sampling sites below the WHO (2004) standards for drinking water.

Nitrate

Nitrate $\left(\mathrm{NO}_{3}{ }^{-}\right)$concentration ranged from 1.0 to 24.77 and 1.11 to $24.89 \mathrm{mg} / \mathrm{L}$ with mean values of 11.58 and 11.89 in the wet and dry seasons, respectively (Tables 1, 2; Fig. 2). The lowest and highest concentrations were recorded at site $51 \mathrm{M}(1.0 \mathrm{mg} / \mathrm{L})$ and $54 \mathrm{~L}(24.88 \mathrm{mg} / \mathrm{L})$, respectively. About $21 \%$ of the sampling sites had values that were below the detection limit $(<0.001 \mathrm{mg} / \mathrm{L})$. All the values were below the WHO (2004) standards for drinking water which is $50 \mathrm{mg} / \mathrm{L}$. Sewages generated from domestic activities could be the sources of $\mathrm{NO}_{3}{ }^{-}$in the area. The 
$\mathrm{NO}_{3}{ }^{-}$could also originate from ammonium and $\mathrm{NO}_{3}{ }^{-}$ fertilizers used in farmlands located along the banks of the river. All the $\mathrm{NO}_{3}{ }^{-}$values were below the $50 \mathrm{mg} / \mathrm{L}$ set by WHO (2004) standard for drinking water.

\section{Sulfate}

Sulfate $\left(\mathrm{SO}_{4}{ }^{2-}\right)$ concentration ranged from 6.89 to $28.11 \mathrm{mg} / \mathrm{L}$ with a mean value of 16.97 in the wet season (Table 1; Fig. 2). The mean for the dry season was $18.0 \mathrm{mg} / \mathrm{L}$ and ranged from 6.56 to $28.11 \mathrm{mg} / \mathrm{L}$ (Table 2; Fig. 2). The sulfate could be released into the water from agricultural and aquaculture activities, oxidation of soil organic matter and sulfate minerals such as gypsum. The desirable limit of $\mathrm{SO}_{4}{ }^{2-}$ for drinking water is specified as $250 \mathrm{mg} / \mathrm{L}$ (WHO 2004). All the values which were recorded in the study area were below the standard.

\section{Phosphate}

Phosphate $\left(\mathrm{PO}_{4}{ }^{3-}\right)$ concentration ranged from 1.33 to 11.67 and 1.44 to $11.67 \mathrm{mg} / \mathrm{L}$ with mean concentrations of 4.73 and $5.23 \mathrm{mg} / \mathrm{L}$ for the wet and dry seasons, respectively (Tables 1, 2; Fig. 2). About $8 \%$ of the sampling sites had values below the detection limit $(<0.001 \mathrm{mg} / \mathrm{L})$. Phosphates are not toxic to people or animals unless they are present in very high levels. Digestive problems could occur from extremely high levels of phosphate (Morrison et al. 2001). Some of the samples (about $37 \%$ ) had values that exceeded the $5 \mathrm{mg} / \mathrm{L}$ set as standard in South Africa (Morrison et al. 2001). Persistence of high concentration of phosphate at this level in the surface water for a long time may lead to eutrophication of the water body, which can reduce their recreational use and also endanger aquatic life. Non-point sources of phosphates may include: natural decomposition of rocks and minerals, agricultural runoff, erosion and direct input by animals/wildlife; whereas point sources may include: aquaculture activities and permitted industrial discharges. Major nutrients including $\mathrm{NO}_{3}{ }^{-}$, $\mathrm{SO}_{4}{ }^{2-}$ and $\mathrm{PO}_{4}{ }^{3-}$ were generally low throughout the study (both wet and dry seasons), even though agricultural and aquaculture activities are taking place in the study area. This is due to the fast mean annual flow of $289 \mathrm{~m}^{3} / \mathrm{s}$ of the Lower Volta River basin (Opoku-Ankomah 1998); hence, some amount of the major nutrients were washed away further downstream before they accumulated.

Dissolved trace metal concentrations

The statistical summary of dissolved metal concentrations in the water samples is also presented in Tables 1 and 2 .
The wide ranges of concentrations of trace metals found in all the sampling sites showed signs of trace metal pollution (Fig. 3).

Total iron $(\mathrm{Fe})$ and manganese $(\mathrm{Mn})$

Iron concentration ranged from 0.032 to $0.344 \mathrm{mg} / \mathrm{L}$ with a mean concentration of $0.091 \mathrm{mg} / \mathrm{L}$ in the wet season (Table 1; Fig. 3). The dry season values varied from 0.032 to $0.348 \mathrm{mg} / \mathrm{L}$. The mean concentration was $0.094 \mathrm{mg} / \mathrm{L}$ (Table 2; Fig. 3). These values were much higher than those recorded $(0.02-0.05 \mathrm{mg} / \mathrm{L})$ by Amoah and Koranteng (2006). The lowest values were recorded at Ad31R, 52R, $69 \mathrm{R}$ and $86 \mathrm{M}, 57 \mathrm{R}$ in both wet and dry seasons, respectively (Fig. 4). About $37 \%$ of the sampling sites recorded values below the detection limit $(<0.006 \mathrm{mg} / \mathrm{L})$. Also, sampling sites $87 \mathrm{~L}, 84 \mathrm{~L}$ and 69R (Fig. 4) recorded values above the WHO (2004) standards for drinking water $(0.300 \mathrm{mg} / \mathrm{L})$; hence, those sites may have taste and esthetic problems (Fatoki et al. 2002). The ingestion of large quantities of iron can damage blood vessels, cause bloody vomitus/stool, and damage the liver and kidneys. The sources of Fe could be due to runoff from urban and domestic activities, corrosion of iron-containing metals and natural deposits. The iron content of river and lake waters also can be influenced by aquatic vegetation, both rooted and free-floating forms (Oborn and Hem 1962). Dissolved Mn ranged from 0.012 to 0.272 and 0.012 to $0.278 \mathrm{mg} / \mathrm{L}$ with mean values of 0.080 and $0.081 \mathrm{mg} / \mathrm{L}$ for the wet season and dry seasons, respectively (Tables 1, 2; Fig. 3). Water sampled at sites $86 \mathrm{M}, 61 \mathrm{R}$ and 70R recorded values below the detection limit $(<0.002 \mathrm{mg} / \mathrm{L}$; Fig. 5). About $71 \%$ of the water sampled had values that fell within the $0.100 \mathrm{mg} / \mathrm{L}$ limit set by WHO (2004) standard for drinking water, while the rest $(29 \%)$ had values above this limit. Runoff from small-scale agro processing and pottery industries and domestic waste could be a major source of $\mathrm{Mn}$ in the study area.

\section{Copper $(\mathrm{Cu})$ and total chromium $(\mathrm{Cr})$}

The minimum value for $\mathrm{Cu}$ in both seasons was $0.016 \mathrm{mg} / \mathrm{L}$ with the maximum of 0.084 and $0.085 \mathrm{mg} / \mathrm{L}$. The mean values were 0.024 and $0.025 \mathrm{mg} / \mathrm{L}$ in the wet and dry seasons, respectively (Table 1, 2; Fig. 3). About $30 \%$ of the sampling sites had values below the detection limit $(<0.003 \mathrm{mg} / \mathrm{L}$; Fig. 6). Apart from its function as a biocatalyst, $\mathrm{Cu}$ is necessary for body pigmentation in addition to $\mathrm{Fe}$ and the maintenance of a healthy central nervous system. The sources of $\mathrm{Cu}$ in the study area may be due to the usage of copper compounds used as

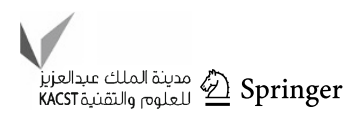



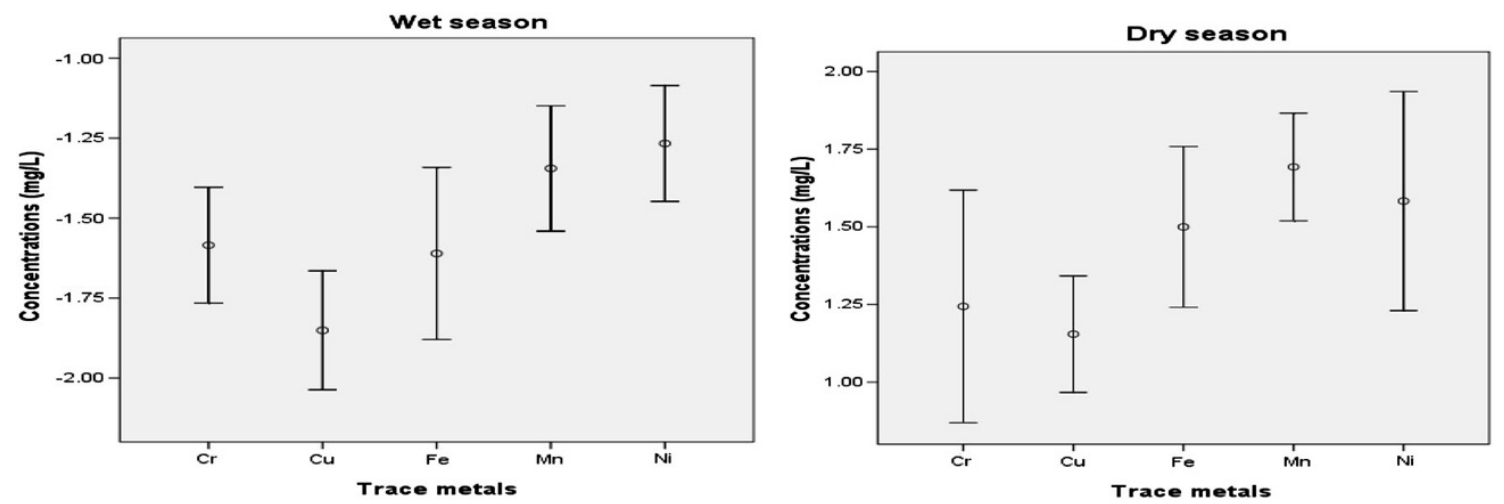

Fig. 3 Standard error bars presenting statistical summaries of the trace metals data for both seasons

Fig. 4 Bar chart of concentration levels of total $\mathrm{Fe}$ (both seasons) compared to WHO standards

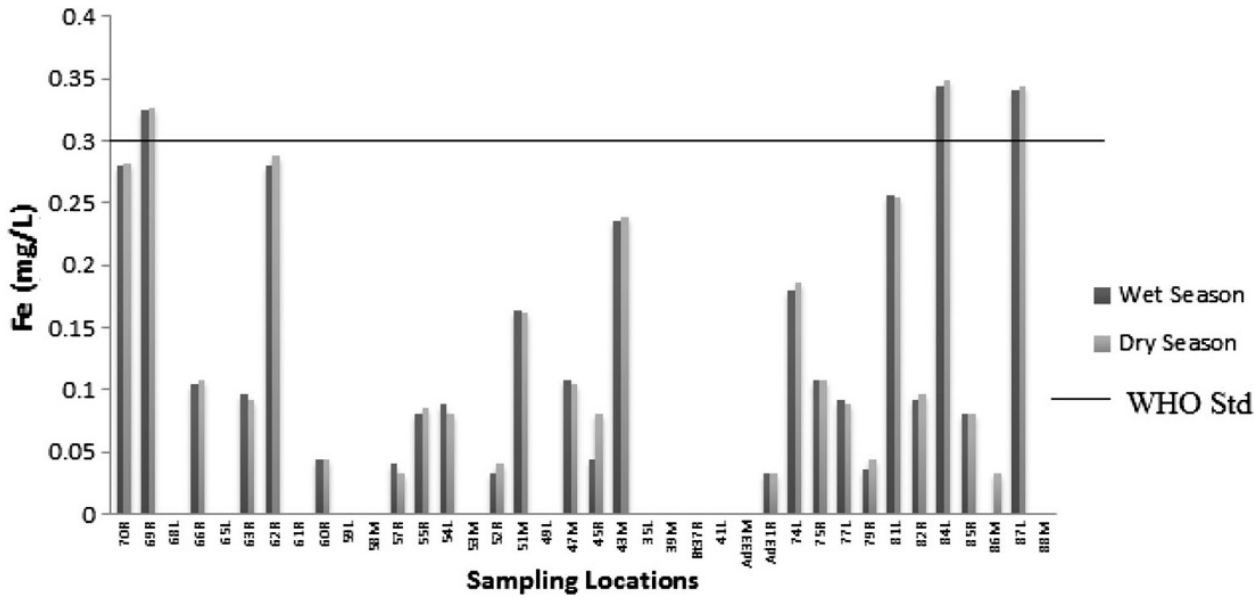

agricultural pesticides and also corrosion of household plumbing systems, erosion of natural deposits which get into the river, and decaying vegetation. All the sampling sites recorded values below the $2 \mathrm{mg} / \mathrm{L}$ set as the maximum that is allowable for drinking water (WHO 2004), hence may not pose any danger to the community. Dissolved $\mathrm{Cr}$ concentration ranged from 0.012 to $0.096 \mathrm{mg} / \mathrm{L}$ and 0.012 and 0.098 with mean concentrations of $0.041 \mathrm{mg} / \mathrm{L}$ and $0.044 \mathrm{mg} / \mathrm{L}$ in the wet and dry seasons, respectively (Tables 1, 2; Fig. 3). Sampling sites 84L, $39 \mathrm{M}, 53 \mathrm{M}$ and $57 \mathrm{R}$ recorded values below the detection limit $(<0.001 \mathrm{mg} / \mathrm{L}$; Fig. 7) representing about $11 \%$. Also, about $55 \%$ of the sampling sites had values below the $0.05 \mathrm{mg} / \mathrm{L}$ set by WHO (2004) standards for drinking water. The rest $(34 \%)$ recorded values above this limit. The sources could be due to wide use of $\mathrm{Cr}$ in metal plating, pigments for paints and effluent from major textile factories upstream.
Fig. 5 Bar chart of concentration levels of Mn (both seasons) compared to WHO standards

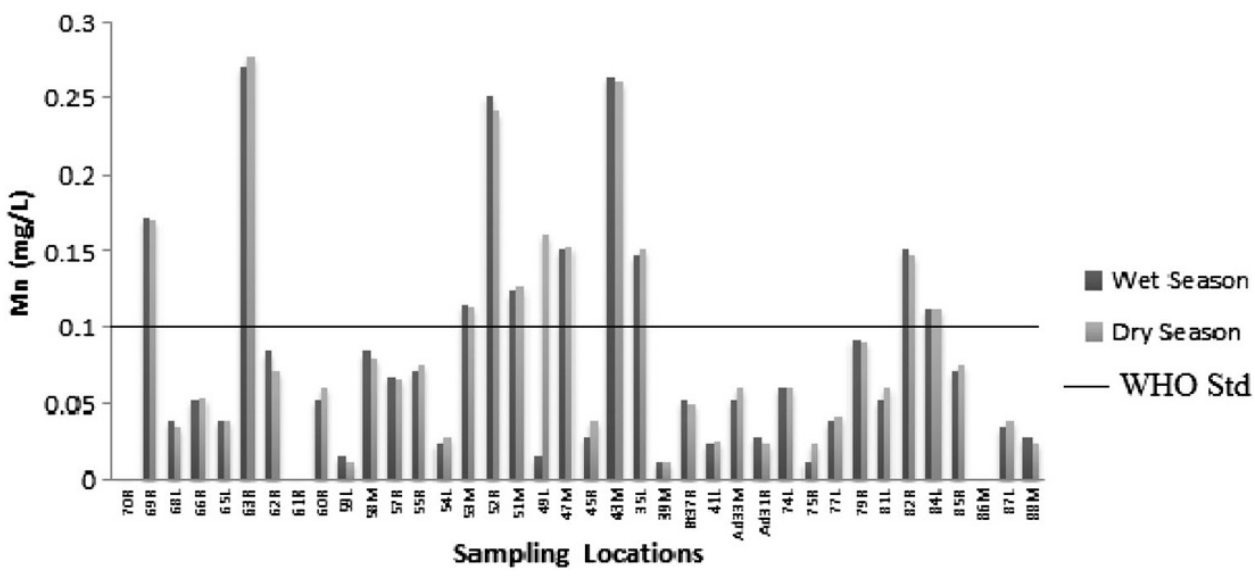


Nickel (Ni)

Nickel concentration ranged from 0.020 to $0.160 \mathrm{mg} / \mathrm{L}$ with a mean concentration of $0.079 \mathrm{mg} / \mathrm{L}$ in the wet season (Table 1; Fig. 3). The dry season varied from 0.020 to $0.162 \mathrm{mg} / \mathrm{L}$ with a mean value of $0.080 \mathrm{mg} / \mathrm{L}$ (Table 2; Fig. 3). Three of the sampling sites $(86 \mathrm{M}, 84 \mathrm{~L}$ and $53 \mathrm{M}$; Fig. 8) recorded values below the detection limit $(<0.001 \mathrm{mg} / \mathrm{L}$ ). All the sampling sites except 63R (Fig. 8) recorded values above the WHO (2004) standard for drinking water which is $0.020 \mathrm{mg} / \mathrm{L}$, representing about $89 \%$. This presents a view of the risk to which consumers are exposed. Larger doses of nickel are carcinogenic and toxic affecting the skin, teeth, and bones of consumers. Therefore, the river water needs to be treated so that the $\mathrm{Ni}$ level meets the required standards before it could be safe for drinking and use for domestic activities. The sources of $\mathrm{Ni}$ in the water samples could come from wastewater releases from the Akosombo and Juapong Textile factories upstream, since nickel is present in nickel acetate which is usually applied as a mordant in textile printing. Runoffs from small scale Brick and Tile factories, commercial effluents (especially car washing) and sewage sludge used as a fertilizer may be a source of nickel in the study area.

Multivariate statistical analysis

\section{Cluster analysis}

Cluster analysis groups variables into clusters on the basis of similarities or dissimilarities such that each cluster represents a specific process in the system. In this study, the hierarchical cluster analysis (HCA) was applied to the raw data in the study area. The result of the HCA is shown in Fig. 9. Three distinct clusters are visible from the results of the HCA.
Fig. 6 Bar chart of concentration levels of $\mathrm{Cu}$ (both seasons) compared to $\mathrm{WHO}$ standards

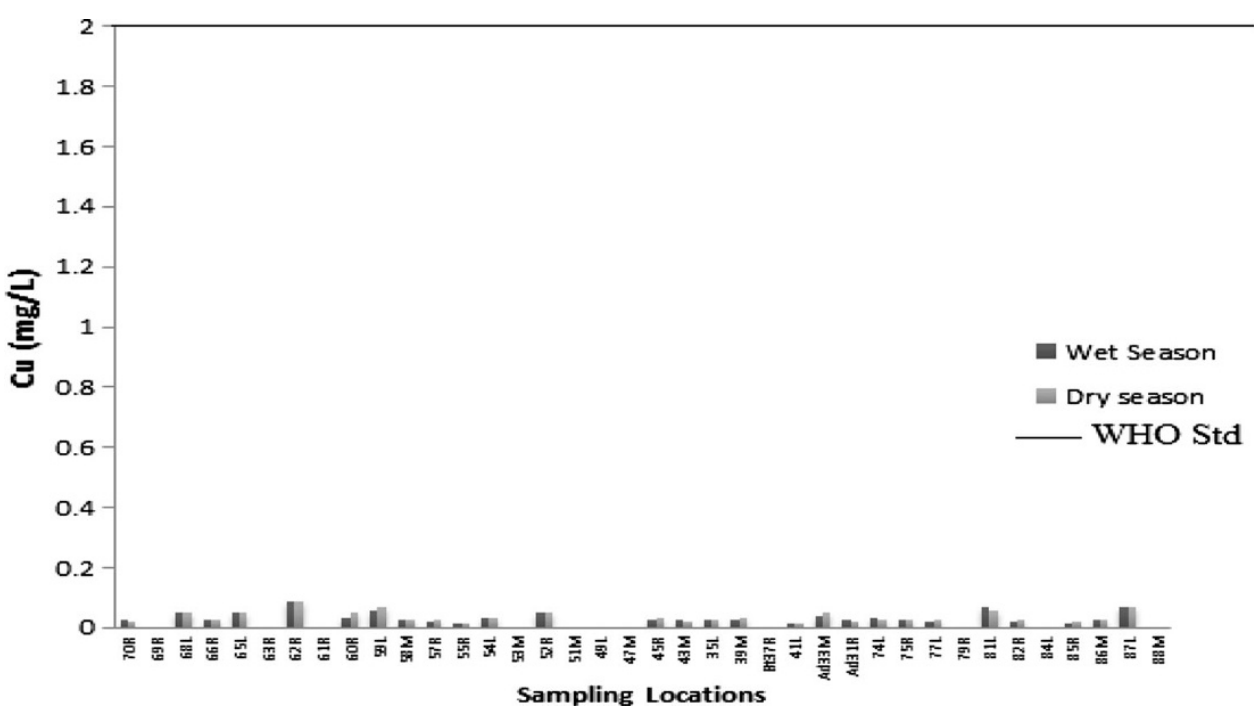

Fig. 7 Bar chart of concentration levels of total $\mathrm{Cr}$ (both seasons) compared to WHO standards

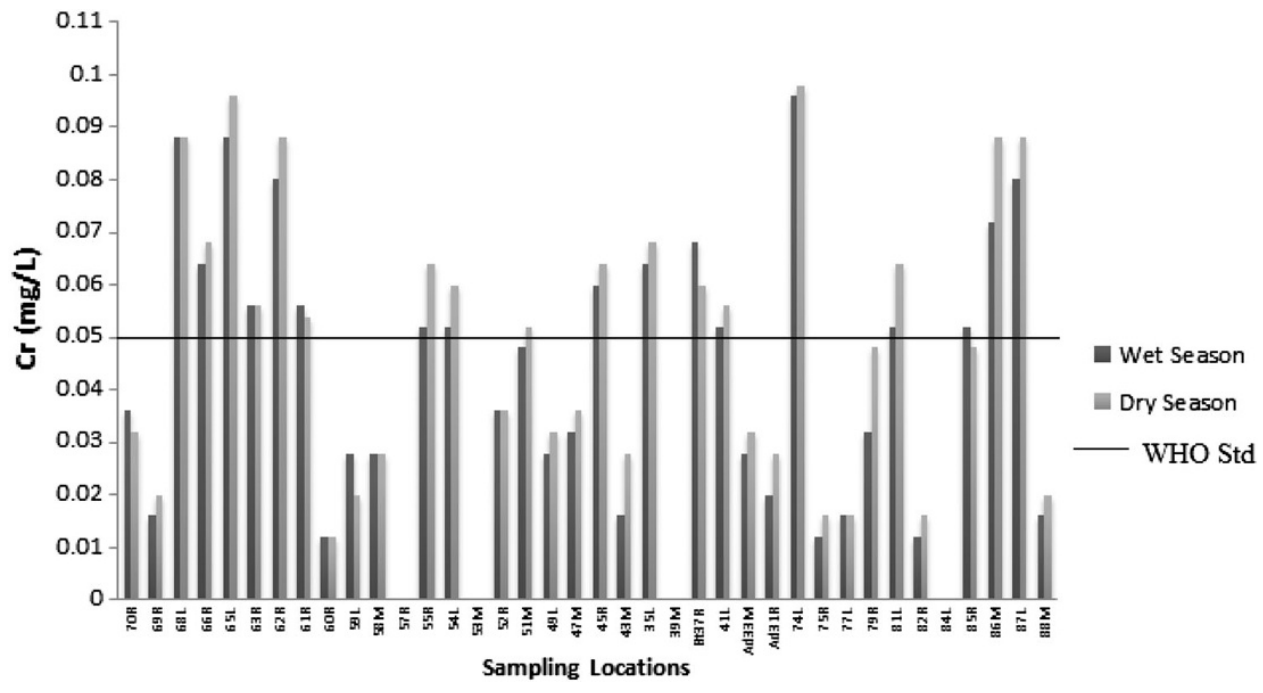


Fig. 8 Bar chart of concentration levels of $\mathrm{Ni}$ (both seasons) compared to $\mathrm{WHO}$ standards

Fig. 9 Dendrogram developed from HCA on data from the Akuse to the Sogakope area

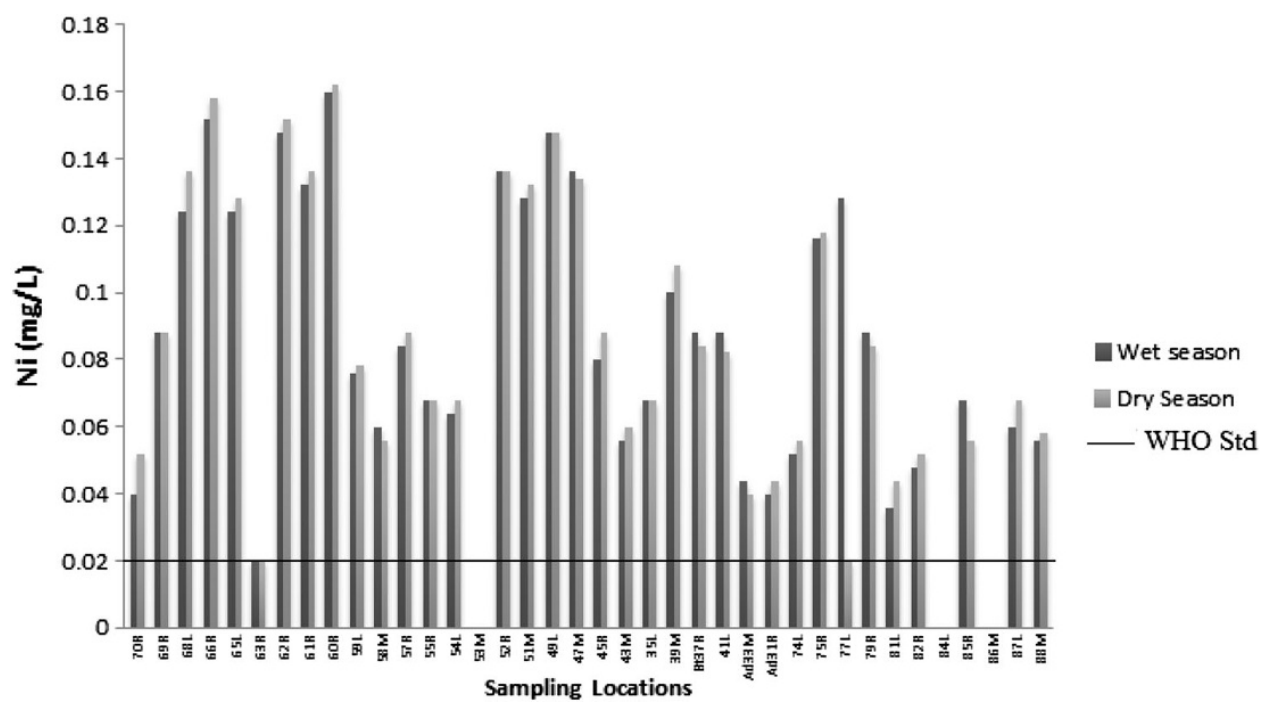

Rescaled Distance Cluster Combine

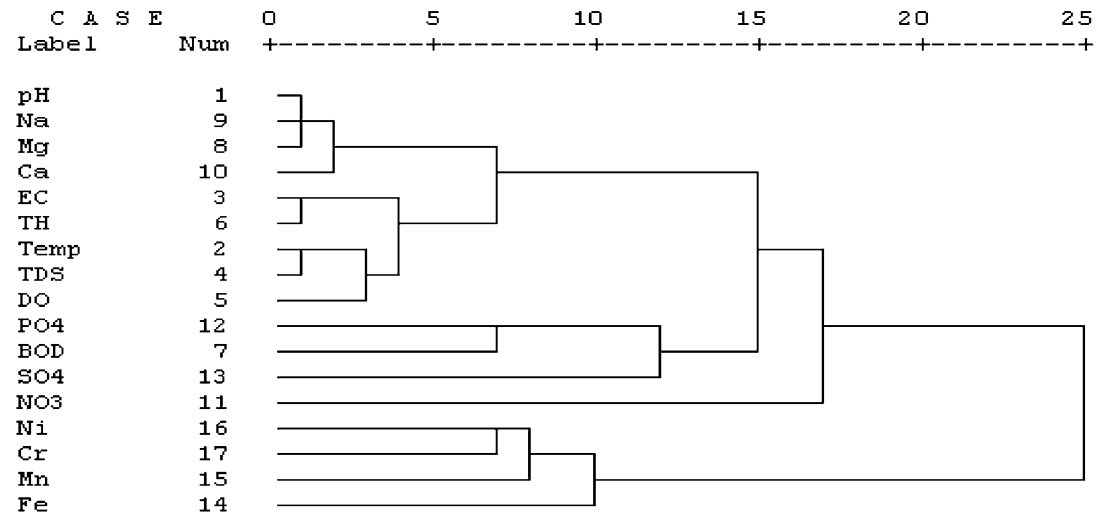

Table 3 Correlation Matrix of physico-chemical parameters at the study area

\begin{tabular}{|c|c|c|c|c|c|c|c|c|c|c|c|c|c|c|c|c|c|c|}
\hline & $\mathrm{pH}$ & Temp & $\mathrm{EC}$ & TDS & DO & $\mathrm{TH}$ & BOD & $\mathrm{Mg}^{2+}$ & $\mathrm{Na}^{+}$ & $\mathrm{Ca}^{2+}$ & $\mathrm{NO}_{3}^{-}$ & $\mathrm{PO}_{4}{ }^{3-}$ & $\mathrm{SO}_{4}{ }^{2-}$ & $\mathrm{Fe}$ & $\mathrm{Mn}$ & $\mathrm{Cu}$ & $\mathrm{Ni}$ & $\mathrm{Cr}$ \\
\hline $\mathrm{pH}$ & 1 & 0.70 & 0.11 & 0.11 & -0.29 & 0.01 & -0.28 & -0.07 & 0.19 & -0.05 & 0.21 & -0.01 & 0.23 & -0.03 & -0.08 & 0.21 & 0.04 & 0.01 \\
\hline Temp & & 1 & 0.09 & 0.01 & -0.36 & -0.11 & -0.51 & -0.11 & 0.19 & -0.18 & 0.32 & -0.04 & 0.15 & 0.18 & 0.01 & 0.19 & -0.15 & -0.12 \\
\hline $\mathrm{EC}$ & & & 1 & 0.72 & 0.08 & -0.07 & 0.19 & -0.01 & 0.53 & -0.15 & 0.48 & -0.22 & 0.15 & 0.10 & -0.01 & -0.13 & 0.06 & 0.03 \\
\hline TDS & & & & 1 & 0.25 & -0.17 & 0.17 & -0.21 & 0.56 & 0.11 & 0.29 & -0.27 & 0.06 & -0.01 & -0.22 & 0.01 & 0.13 & 0.28 \\
\hline DO & & & & & 1 & 0.24 & 0.36 & 0.20 & -0.01 & 0.12 & -0.14 & 0.02 & 0.11 & 0.11 & 0.08 & 0.04 & -0.09 & 0.06 \\
\hline $\mathrm{TH}$ & & & & & & 1 & -0.50 & 0.81 & -0.13 & 0.01 & -0.12 & 0.14 & 0.16 & -0.05 & -0.12 & -0.22 & -0.35 & -0.39 \\
\hline BOD & & & & & & & 1 & -0.25 & -0.05 & 0.01 & -0.01 & -0.14 & -0.14 & 0.08 & 0.11 & 0.24 & 0.57 & 0.33 \\
\hline $\mathrm{Mg}^{2+}$ & & & & & & & & 1 & -0.16 & -0.41 & 0.08 & 0.15 & -0.01 & -0.05 & 0.10 & -0.21 & -0.16 & -0.35 \\
\hline $\mathrm{Na}^{+}$ & & & & & & & & & 1 & 0.06 & 0.07 & -0.22 & -0.03 & -0.20 & 0.03 & -0.21 & 0.06 & -0.03 \\
\hline $\mathrm{Ca}^{2+}$ & & & & & & & & & & 1 & -0.41 & -0.11 & 0.27 & -0.27 & -0.26 & 0.14 & -0.21 & 0.14 \\
\hline $\mathrm{NO}_{3}^{-}$ & & & & & & & & & & & 1 & 0.18 & -0.09 & 0.12 & 0.03 & 0.08 & 0.01 & -0.08 \\
\hline $\mathrm{PO}_{4}{ }^{3-}$ & & & & & & & & & & & & 1 & 0.09 & 0.16 & 0.33 & -0.03 & 0.01 & -0.23 \\
\hline $\mathrm{SO}_{4}{ }^{2-}$ & & & & & & & & & & & & & 1 & 0.11 & 0.01 & -0.11 & -0.17 & -0.03 \\
\hline $\mathrm{Fe}$ & & & & & & & & & & & & & & 1 & 0.24 & 0.02 & 0.03 & -0.03 \\
\hline $\mathrm{Mn}$ & & & & & & & & & & & & & & & 1 & -0.18 & 0.12 & -0.11 \\
\hline $\mathrm{Cu}$ & & & & & & & & & & & & & & & & 1 & 0.19 & 0.23 \\
\hline $\mathrm{Ni}$ & & & & & & & & & & & & & & & & & 1 & 0.39 \\
\hline $\mathrm{Cr}$ & & & & & & & & & & & & & & & & & & 1 \\
\hline
\end{tabular}


Table 4 Pearson's correlation for some sampling sites in terms of physico-chemical parameters

\begin{tabular}{|c|c|c|c|c|c|c|c|c|c|c|c|c|c|}
\hline & $66 \mathrm{R}$ & $62 \mathrm{R}$ & $60 \mathrm{R}$ & $58 \mathrm{M}$ & $57 \mathrm{R}$ & $55 \mathrm{R}$ & $54 \mathrm{~L}$ & $52 \mathrm{R}$ & $51 \mathrm{M}$ & $47 \mathrm{M}$ & $45 \mathrm{R}$ & $43 \mathrm{M}$ & $35 \mathrm{~L}$ \\
\hline 66R & 1.00 & 0.95 & 0.79 & 0.96 & 0.96 & 0.96 & 0.97 & 0.92 & 0.84 & 0.96 & 0.78 & 0.94 & 0.98 \\
\hline $62 \mathrm{R}$ & & 1.00 & 0.90 & 0.91 & 0.93 & 0.91 & 0.91 & 0.93 & 0.79 & 0.90 & 0.86 & 0.93 & 0.94 \\
\hline $60 \mathrm{R}$ & & & 1.00 & 0.95 & 0.95 & 0.95 & 0.96 & 0.91 & 0.84 & 0.94 & 0.79 & 0.90 & 0.97 \\
\hline $58 \mathrm{M}$ & & & & 1.00 & 0.99 & 0.99 & 0.99 & 0.93 & 0.83 & 0.99 & 0.70 & 0.89 & 0.92 \\
\hline $57 \mathrm{R}$ & & & & & 1.00 & 0.99 & 0.98 & 0.97 & 0.84 & 0.98 & 0.76 & 0.91 & 0.93 \\
\hline $55 \mathrm{R}$ & & & & & & 1.00 & 0.99 & 0.95 & 0.85 & 0.99 & 0.71 & 0.90 & 0.94 \\
\hline $54 \mathrm{~L}$ & & & & & & & 1.00 & 0.94 & 0.85 & 1.00 & 0.72 & 0.91 & 0.93 \\
\hline $52 \mathrm{R}$ & & & & & & & & 1.00 & 0.83 & 0.94 & 0.82 & 0.88 & 0.92 \\
\hline $51 \mathrm{M}$ & & & & & & & & & 1.00 & 0.84 & 0.76 & 0.70 & 0.79 \\
\hline $47 \mathrm{M}$ & & & & & & & & & & 1.00 & 0.70 & 0.89 & 0.91 \\
\hline $45 \mathrm{R}$ & & & & & & & & & & & 1.00 & 0.72 & 0.79 \\
\hline $43 \mathrm{M}$ & & & & & & & & & & & & 1.00 & 0.91 \\
\hline $35 \mathrm{~L}$ & & & & & & & & & & & & & 1.00 \\
\hline
\end{tabular}

Bt37R

41L

$\operatorname{Ad} 33 \mathrm{M}$

$\operatorname{Ad} 31 \mathrm{R}$

75R

77L

$79 \mathrm{R}$

$82 \mathrm{R}$

84L

$85 \mathrm{R}$

87L

$88 \mathrm{M}$

\begin{tabular}{|c|c|c|c|c|c|c|c|c|c|c|c|c|}
\hline & $\mathrm{Bt} 37 \mathrm{R}$ & $41 \mathrm{~L}$ & Ad33M & Ad31R & $75 \mathrm{R}$ & $77 \mathrm{~L}$ & $79 \mathrm{R}$ & $82 \mathrm{R}$ & $84 \mathrm{~L}$ & $85 \mathrm{R}$ & $87 \mathrm{~L}$ & $88 \mathrm{M}$ \\
\hline $66 \mathrm{R}$ & 0.78 & 0.95 & 0.97 & 0.98 & 0.99 & 0.99 & 0.95 & 0.86 & 0.77 & 0.95 & 0.96 & 0.76 \\
\hline $62 \mathrm{R}$ & 0.86 & 0.89 & 0.92 & 0.93 & 0.97 & 0.97 & 0.92 & 0.79 & 0.88 & 0.90 & 0.93 & 0.85 \\
\hline $60 \mathrm{R}$ & 0.80 & 0.97 & 0.99 & 0.97 & 0.97 & 0.98 & 0.95 & 0.86 & 0.76 & 0.94 & 0.97 & 0.76 \\
\hline $58 \mathrm{M}$ & 0.73 & 0.96 & 0.91 & 0.97 & 0.95 & 0.96 & 0.92 & 0.85 & 0.76 & 0.95 & 0.92 & 0.80 \\
\hline $57 \mathrm{R}$ & 0.79 & 0.96 & 0.92 & 0.98 & 0.97 & 0.97 & 0.94 & 0.87 & 0.82 & 0.96 & 0.93 & 0.85 \\
\hline $55 \mathrm{R}$ & 0.73 & 0.96 & 0.91 & 0.98 & 0.96 & 0.96 & 0.95 & 0.88 & 0.77 & 0.95 & 0.92 & 0.80 \\
\hline $54 \mathrm{~L}$ & 0.75 & 0.96 & 0.93 & 0.98 & 0.97 & 0.97 & 0.93 & 0.88 & 0.77 & 0.97 & 0.92 & 0.80 \\
\hline $52 \mathrm{R}$ & 0.83 & 0.94 & 0.89 & 0.95 & 0.94 & 0.94 & 0.95 & 0.85 & 0.89 & 0.92 & 0.88 & 0.87 \\
\hline $51 \mathrm{M}$ & 0.76 & 0.86 & 0.82 & 0.85 & 0.83 & 0.82 & 0.78 & 0.97 & 0.73 & 0.80 & 0.77 & 0.81 \\
\hline $47 \mathrm{M}$ & 0.73 & 0.95 & 0.90 & 0.97 & 0.95 & 0.95 & 0.91 & 0.87 & 0.76 & 0.96 & 0.90 & 0.80 \\
\hline $45 \mathrm{R}$ & 0.99 & 0.82 & 0.83 & 0.75 & 0.79 & 0.82 & 0.77 & 0.67 & 0.95 & 0.74 & 0.82 & 0.90 \\
\hline $43 \mathrm{M}$ & 0.72 & 0.84 & 0.90 & 0.89 & 0.97 & 0.94 & 0.90 & 0.78 & 0.75 & 0.94 & 0.88 & 0.71 \\
\hline $35 \mathrm{~L}$ & 0.78 & 0.93 & 0.96 & 0.97 & 0.96 & 0.97 & 0.97 & 0.81 & 0.77 & 0.89 & 0.96 & 0.72 \\
\hline Bt37R & 1.00 & 0.84 & 0.83 & 0.77 & 0.79 & 0.83 & 0.76 & 0.67 & 0.96 & 0.77 & 0.83 & 0.93 \\
\hline $41 \mathrm{~L}$ & & 1.00 & 0.95 & 0.96 & 0.93 & 0.96 & 0.93 & 0.85 & 0.82 & 0.94 & 0.95 & 0.84 \\
\hline Ad33M & & & 1.00 & 0.95 & 0.95 & 0.97 & 0.93 & 0.83 & 0.78 & 0.93 & 0.97 & 0.75 \\
\hline Ad31R & & & & 1.00 & 0.97 & 0.97 & 0.96 & 0.88 & 0.78 & 0.93 & 0.94 & 0.78 \\
\hline $75 \mathrm{R}$ & & & & & 1.00 & 0.99 & 0.95 & 0.88 & 0.80 & 0.96 & 0.94 & 0.80 \\
\hline $77 \mathrm{~L}$ & & & & & & 1.00 & 0.96 & 0.84 & 0.83 & 0.95 & 0.97 & 0.81 \\
\hline $79 \mathrm{R}$ & & & & & & & 1.00 & 0.82 & 0.79 & 0.89 & 0.92 & 0.75 \\
\hline $82 \mathrm{R}$ & & & & & & & & 1.00 & 0.67 & 0.84 & 0.76 & 0.75 \\
\hline $84 \mathrm{~L}$ & & & & & & & & & 1.00 & 0.78 & 0.79 & 0.96 \\
\hline $85 \mathrm{R}$ & & & & & & & & & & 1.00 & 0.90 & 0.81 \\
\hline $87 \mathrm{~L}$ & & & & & & & & & & & 1.00 & 0.76 \\
\hline $88 \mathrm{M}$ & & & & & & & & & & & & 1.00 \\
\hline
\end{tabular}


Cluster 1 comprises $\mathrm{pH}, \mathrm{Na}^{+}, \mathrm{Mg}^{2+}, \mathrm{Ca}^{2+}, \mathrm{EC}, \mathrm{TH}$, temperature, TDS and DO and reflects the joint effect they produced on decay of organic matter from plant debris, precipitation to water chemistry and household wastewaters which contain concentrations of $\mathrm{Mg}^{2+}, \mathrm{Ca}^{2+}$ and $\mathrm{Na}^{+}$ from salts and soaps. Cluster 2 comprises $\mathrm{PO}_{4}{ }^{3-}$, BOD, $\mathrm{SO}_{4}{ }^{2-}$ and $\mathrm{NO}_{3}{ }^{-}$and reflects the contribution of organic and artificial fertilizers from agricultural and aquaculture activities in the area. Cluster 3 comprises $\mathrm{Ni}$, total $\mathrm{Cr}, \mathrm{Mn}$, $\mathrm{Cu}$ and total $\mathrm{Fe}$ and represents the contribution of industrial wastewaters from major textile factories upstream, domestic wastes, pesticides and herbicides and fishing activities in the study area.

\section{PCA/FA and Pollution identification}

PCA was applied to standardized log-transformed data set to identify the latent factors. The objective of this analysis was primarily to create an entirely new set of factors much smaller in number when compared with the original data set in subsequent analysis. Only factors with eigen values greater than or equal to 1 will be accepted as possible sources of variance in the data.

Pattern recognition of correlations among the parameters was summarized by PCA. Table 3 represents the correlation matrix among the surface water quality parameters in the study area. Overall, the correlations between variables were relatively weak. The high positively correlated values were found between $\mathrm{EC}$ and TDS, $\mathrm{pH}$ and temperature $\mathrm{TH}$ and $\mathrm{Mg}^{2+}, \mathrm{EC}$ and $\mathrm{Na}^{+}$, TDS and $\mathrm{Na}^{+}, \mathrm{BOD}$ and $\mathrm{Ni}$. The good correlation suggests the interdependence between these variables. The negative correlations were revealed between some variables such as temperature and BOD, TH and BOD, $\mathrm{Mg}^{2+}$ and $\mathrm{Ca}^{2+}$ and so on. The negative correlation obtained between temperature and BOD (Table 3) indicates that the BOD is largely influenced by temperature in the study area. The strong positive correlation between $\mathrm{TH}$ and $\mathrm{Mg}^{2+}$ as compared to $\mathrm{Ca}^{2+}$ (Table 3) indicates that $\mathrm{TH}$ results from only $\mathrm{Mg}^{2+}$ in the study area. Correlation analysis was also carried out between some of the sampling sites (Table 4) and it was realized that all the sites strongly correlated with each other in terms of physico-chemical parameters. This is an indication that the parameters were from the same source which is anthropogenic (industrial, domestic and agricultural activities). It also means that physico-chemical parameters in the study area did not change much from one sampling site to the other.

Five principal components, which accounted for about $65.59 \%$ (Table 5) of the total variance, were extracted for varimax rotation. The bold values in Tables 5 and 7 indicate absolute component loadings higher than 0.5 , which are considered significant contributors to the variance in the hydrochemistry. Table 5 presents the rotated factor matrix. PC 1 contains high loadings for $\mathrm{TH}$, BOD, $\mathrm{Mg}^{2+}$, Ni and total $\mathrm{Cr}$ and represents $18.37 \%$ of the total variance. PC 1 represents the contribution of industrial activities upstream and decomposition of organic materials by microbial organisms. PC 2 represents $15.72 \%$ of the total variance with high loadings for EC, TDS, $\mathrm{Na}^{+}$and $\mathrm{NO}_{3}{ }^{-}$. PC 2 represents the contribution of domestic wastewaters and leaching of soil contaminant in the study area. PC 3 explaining $11.96 \%$ of the total variance has strong positive loadings on $\mathrm{pH}$, temperature and strong negative loadings on DO and BOD. The inverse relationship between temperature and DO is a natural process because warm water easily becomes saturated with oxygen and thus can hold less DO (Shrestha and Kazama 2007; Wu et al. 2009). PC 4 contains high loadings for $\mathrm{PO}_{4}{ }^{3-}$, total $\mathrm{Fe}$ and $\mathrm{Mn}$ and represents $11.62 \%$ of the total variance. PC 5 has high loadings for $\mathrm{Ca}^{2+}$ and $\mathrm{SO}_{4}{ }^{2-}$, accounting for $7.93 \%$ of the total variance in the study area. PC 4 and PC 5 represent industrial activities upstream and agricultural activities.

Table 5 Rotated component matrix for water quality parameters

\begin{tabular}{|c|c|c|c|c|c|}
\hline \multicolumn{6}{|c|}{ Rotated component matrix ${ }^{a}$} \\
\hline & \multicolumn{5}{|c|}{ Component } \\
\hline & 1 & 2 & 3 & 4 & 5 \\
\hline $\mathrm{pH}$ & -0.008 & 0.156 & 0.792 & -0.003 & 0.085 \\
\hline Temp & -0.028 & 0.105 & 0.894 & 0.126 & 0.013 \\
\hline EC & 0.001 & 0.916 & 0.047 & 0.061 & -0.081 \\
\hline TDS & -0.142 & 0.880 & -0.047 & -0.179 & 0.091 \\
\hline DO & 0.277 & 0.287 & -0.611 & 0.197 & 0.299 \\
\hline $\mathrm{TH}$ & 0.918 & -0.074 & -0.076 & -0.063 & 0.133 \\
\hline BOD & -0.536 & 0.213 & -0.588 & 0.140 & -0.146 \\
\hline $\mathrm{Mg}^{2+}$ & 0.874 & -0.026 & -0.130 & 0.086 & -0.287 \\
\hline $\mathrm{Na}^{+}$ & -0.179 & 0.657 & 0.135 & -0.238 & 0.038 \\
\hline $\mathrm{Ca}^{2+}$ & -0.196 & -0.092 & -0.133 & -0.364 & 0.769 \\
\hline $\mathrm{NO}_{3}^{-}$ & 0.112 & 0.552 & 0.365 & 0.249 & -0.455 \\
\hline $\mathrm{PO}_{4}{ }^{3-}$ & 0.164 & -0.279 & 0.035 & 0.593 & -0.018 \\
\hline $\mathrm{SO}_{4}{ }^{2-}$ & 0.124 & 0.153 & 0.180 & 0.305 & 0.718 \\
\hline $\mathrm{Fe}$ & -0.035 & 0.070 & 0.046 & 0.702 & 0.026 \\
\hline $\mathrm{Mn}$ & -0.146 & -0.061 & -0.122 & 0.691 & -0.133 \\
\hline $\mathrm{Cu}$ & -0.193 & -0.121 & 0.174 & -0.066 & -0.021 \\
\hline $\mathrm{Ni}$ & -0.585 & 0.085 & -0.182 & 0.096 & -0.419 \\
\hline $\mathrm{Cr}$ & -0.513 & 0.118 & -0.177 & -0.161 & 0.028 \\
\hline Eigen values & 3.126 & 2.650 & 2.152 & 2.091 & 1.428 \\
\hline$\%$ of variance & 18.367 & 15.720 & 11.955 & 11.618 & 7.931 \\
\hline Cumulative $\%$ & 18.367 & 34.087 & 46.042 & 57.660 & 65.591 \\
\hline
\end{tabular}

Extraction method: principal component analysis, rotation method: varimax with Kaiser normalization

${ }^{\text {a }}$ Rotation converged in eight iterations 
Table 6 Extraction values of the total variance using principal component analysis for sampling sites based on physico-chemical parameters

\begin{tabular}{|c|c|c|c|c|c|c|}
\hline \multirow[t]{2}{*}{ Component } & \multicolumn{3}{|c|}{ Extraction sums of squared loadings } & \multicolumn{3}{|c|}{ Rotation sums of squared loadings } \\
\hline & Total & $\%$ of variance & Cumulative $\%$ & Total & $\%$ of variance & Cumulative $\%$ \\
\hline 1 & 33.594 & 88.405 & 88.405 & 22.753 & 59.875 & 59.875 \\
\hline 2 & 2.014 & 5.299 & 93.704 & 12.855 & 33.829 & 93.704 \\
\hline
\end{tabular}

\section{Pollution identification}

The extraction values of the total variance using PCA for the sampling sites, based on the physico-chemical parameters are presented in Table 6.

Principal component 1(PC1) (Table 6) exhibits $88.40 \%$ of the total variance with highest loadings on $70 \mathrm{R}, 66 \mathrm{R}$, 65L, 61R, 60R, 59L, 58M, 57R, 55R, 54L, 85R, 86M, 88M, 49R, 39M, 47M, 45R, 41L, Bt37R, 53M, Ad33M, Ad31R, 79R, 81L and 82R (Table 7). Since these sites had moderate concentrations of dissolved trace metals, nutrients and physical parameters and also recorded some values that fell within the WHO (2004) standards for drinking water according to the data, they could be considered unpolluted sites.

Principal component 2 (PC2) (Table 6) exhibits $5.29 \%$ of the total variance, with high loadings on 69R, 63R, 51M, $87 \mathrm{~L}, 35 \mathrm{~L}, 74 \mathrm{~L}$ and $84 \mathrm{~L}$ (Table 7). Based on the data, the above mentioned sites may be considered as 'polluted' sites because most of these sites had at least two metal values above the WHO (2004) standards for drinking water or recorded the highest concentration for a particular metal. The rest of the sampling sites $(68 \mathrm{~L}, 62 \mathrm{R}, 52 \mathrm{R}, 43 \mathrm{M}, 75 \mathrm{R}$ and $77 \mathrm{~L}$ ) were considered as 'semi-polluted' sites based on the metal data. In general, most of the pollution sources in the study area came from large and small-scale factories both up and downstream, domestic waste, agricultural and fishing activities and animal husbandry.

\section{Conclusion}

River water is an important source of drinking water for many people around the world. Contamination of river water generally results in poor drinking water quality, loss of water supply, high cleanup costs, high-cost alternative water supplies and potential health problem. In the present study, interpretation of the data reveals that the physical and ionic parameters were mostly found within the WHO (2004) standards for drinking water. Trace metals (total Fe, $\mathrm{Mn}, \mathrm{Ni}$, and total $\mathrm{Cr}$ ) except $\mathrm{Cu}$ at some sites recorded concentrations above the WHO (2004) standards for drinking water. At sites where total $\mathrm{Fe}, \mathrm{Mn}$ and total $\mathrm{Cr}$ concentrations were within standard limits, $\mathrm{Ni}$ concentrations were observed to be above standard. Cluster analysis
Table 7 Rotated component matrix for sampling sites, based on physico-chemical parameters

\begin{tabular}{|c|c|c|}
\hline \multirow[t]{2}{*}{ Sampled Sites } & \multicolumn{2}{|c|}{ Component } \\
\hline & 1 & 2 \\
\hline $70 \mathrm{R}$ & 0.828 & 0.537 \\
\hline $69 \mathrm{R}$ & 0.436 & 0.898 \\
\hline $68 \mathrm{~L}$ & 0.501 & 0.702 \\
\hline $66 \mathrm{R}$ & 0.891 & 0.440 \\
\hline $65 \mathrm{~L}$ & 0.838 & 0.405 \\
\hline $63 \mathrm{R}$ & 0.468 & 0.866 \\
\hline $62 \mathrm{R}$ & 0.751 & 0.615 \\
\hline $61 \mathrm{R}$ & 0.847 & 0.478 \\
\hline $60 \mathrm{R}$ & 0.748 & 0.634 \\
\hline $59 \mathrm{~L}$ & 0.833 & 0.317 \\
\hline $58 \mathrm{M}$ & 0.856 & 0.455 \\
\hline $57 \mathrm{R}$ & 0.830 & 0.526 \\
\hline $55 \mathrm{R}$ & 0.872 & 0.447 \\
\hline $54 \mathrm{~L}$ & 0.874 & 0.448 \\
\hline $53 \mathrm{M}$ & 0.871 & 0.464 \\
\hline $52 \mathrm{R}$ & 0.756 & 0.606 \\
\hline $51 \mathrm{M}$ & 0.396 & 0.820 \\
\hline $85 \mathrm{R}$ & 0.893 & 0.436 \\
\hline $86 \mathrm{M}$ & 0.856 & 0.452 \\
\hline $87 \mathrm{~L}$ & 0.436 & 0.854 \\
\hline $88 \mathrm{M}$ & 0.840 & 0.419 \\
\hline $49 \mathrm{~L}$ & 0.873 & 0.434 \\
\hline $47 \mathrm{M}$ & 0.872 & 0.475 \\
\hline $45 \mathrm{R}$ & 0.832 & 0.475 \\
\hline $43 \mathrm{M}$ & 0.795 & 0.555 \\
\hline $35 \mathrm{~L}$ & 0.444 & 0.874 \\
\hline $39 \mathrm{M}$ & 0.881 & 0.447 \\
\hline Bt37R & 0.834 & 0.549 \\
\hline $41 \mathrm{~L}$ & 0.866 & 0.481 \\
\hline $\operatorname{Ad} 33 \mathrm{M}$ & 0.846 & 0.520 \\
\hline Ad31R & 0.858 & 0.444 \\
\hline $74 \mathrm{~L}$ & 0.444 & 0.881 \\
\hline $75 \mathrm{R}$ & 0.795 & 0.393 \\
\hline $77 \mathrm{~L}$ & 0.792 & 0.547 \\
\hline $79 \mathrm{R}$ & 0.821 & 0.494 \\
\hline $81 \mathrm{~L}$ & 0.831 & 0.524 \\
\hline $82 \mathrm{R}$ & 0.816 & 0.507 \\
\hline $84 \mathrm{~L}$ & 0.433 & 0.878 \\
\hline
\end{tabular}

Rotation converged in three iterations

Extraction method: principal component analysis, rotation method: varimax with Kaiser normalization 
grouped the physico-chemical parameters into three distinct groups (physical/minor ions, major ions and trace elements). Correlation analysis showed that physico-chemical parameters do not vary much in terms of the sampling sites. Hence, based on established information, it is possible to design a future, optimal sampling strategy, which could reduce the number of sampling stations and associated costs. The FA assisted to extract and recognize the factors or origins responsible for water quality variations. FA identified four latent factors that explained $65.59 \%$ of total variance, namely industrial effect, domestic factor, natural source and agricultural effect. PCA/FA also identified sampling sites 69R, 63R, 51M, 87L, 35L, 74L and 84L as polluted with trace metals and suggests the use of dissolved trace metals as important water quality parameters. Since trace metals will accumulate in living organisms and cause acute effects, thus adding them as water quality parameters is laudable. The hydrochemistry of the river water is controlled largely by effluent from major textile factories located upstream, domestic waste, agricultural and fishing activities and the decay of organic matter from the vegetation surrounding the river. It is therefore observed that the water source from the studied area has a lot of potentials for wide applications to the people, if only they can be subjected to further treatments that will reduce the concentration of the few identified elements that may pose some danger to health and society.

Acknowledgments The authors are very grateful to the Ghana Atomic energy Commission and Graduate School of Nuclear and Allied Sciences, University of Ghana, Legon, Accra for equipment and expertise support.

Open Access This article is distributed under the terms of the Creative Commons Attribution License which permits any use, distribution, and reproduction in any medium, provided the original author(s) and the source are credited.

\section{References}

Abdul-Wahab SA, Bakheit CS, Al-Alawi SM (2005) Principal component and multiple regression analysis in modelling of ground-level ozone and factors affecting its concentrations. Environ Model Softw 20(10):1263-1271

Abubacker MN, Kannan V, Sridharan VT, Chandramohan M, Rajavelu S (1996) Physico-chemical and biological studies on Uyya Kondan Canal water of River Cauvery. Pollut Res 15(3):257-259

Adams S, Titus R, Pietesen K, Tredoux G, Harris C (2001) Hydrochemical characteristic of aquifers near Sutherland in the Western Karoo, South Africa. J Hydrol 241:91-103

Amoah C, Koranteng SS (2006) Volta Basin Research Project (VBRP). University of Ghana, Legon

APHA (1998) Standard methods for the examination of water and wastewater, 20th edn. American Public Health Association, New York
Best MA, Wither AW, Coates S (2007) Dissolved oxygen as a physico-chemical supporting element in the water framework directive. Mar Pollut Bull 55(1-6):53-64

Brumelis G, Lapina L, Nikodemus O, Tabors G (2000) Use of an artificial model of monitoring data to aid interpretation of principal component analysis. Environ Model Softw 15(8):755-763

Davis SN, De Wiest RJM (1966) Hydrogeology, vol 463. Wiley, New York

Durfor CN, Becker E (1964) Public water supplies of the 100 largest cities in the United States, 1962, US Geological Survey WaterSupply Paper 1812, p 364

Eaton AD, Clesceri LS, Greengerg AE (eds) (2005) Standard methods for the examination of water and wastewater. American Public Health Association, Washington

Fatoki OS, Lujiza N, Ogunfowokan AO (2002) Levels of Cd, Hg and $\mathrm{Zn}$ in some surface waters from the Eastern Cape Province, South Africa. Water S Afr 29(4):375

Freeze RA, Cherry JA (1979) Groundwater. Prentice-Hall, Englewood Cliffs

Guler C, Thyne GD (2004) Hydrologic and geologic factors controlling surface and groundwater chemistry in Indian wells-Owens Valley area, southeastern California, USA. J Hydrol 285:177-198

Helena B, Pardo R, Vega M, Barrado E, Ferna'ndez JM, Ferna'ndez L (2000) Temporal evolution of groundwater composition in an alluvial aquifer (Pisuerga river, Spain) by principal component analysis. Water Res 34:807-816

Hem JD (1985) Study and interpretation of the chemical characteristics of natural waters, 3rd edn. USGS Water Supply Paper, vol 2254. pp 117-120

Kataria HC, Quershi HA, Iqbal SA, Shandilya AK (1996) Assessment of water quality of Kolar reservoir in Bhopal (M.P.). Pollut Res 15(2):191-193

Kney AD, Brandes D (2007) A graphical screening method for assessing stream water quality using specific conductivity and alkalinity data. J Environ Manag 82(4):519-528

Lee JY, Cheon JY, Lee KK, Lee SY, Lee MH (2001) Statistical evaluation of geochemical parameter distribution in a ground water system contaminated with petroleum hydrocarbons. J Environ Qual 30:1548-1563

McKenna JE Jr (2003) An enhanced cluster analysis program with bootstrap significance testing for ecological community analysis. Environ Model Softw 18(3):205-220

Ministry of Local Government and Rural Development, Ghana (2010)

Morrison G, Fatoki OS, Ekberg A (2001) Assessment of the impact of point source pollution from Keiskammahoek sewage treatment plant on the Keiskamma River- $\mathrm{pH}$, electrical conductivity, oxygen-demanding substances (COD) and nutrients. Water SA 27:475-480

Morrissette DG, Mavinic DS (1978) BOD test variables. J Environ: Eng Div EP 6:1213-1222

Moss B (1972) Studies on Gull Lake, Michigan II. Eutrophication evidence and prognosis. Fresh Water Biol 2:309-320

Oborn ET, Hem JD (1962) Some effects of the larger types of aquatic vegetation on iron content of water: US Geological Survey Water Supply Paper 1459-L, pp 237-268

Opoku-Ankomah Y (1998) Volta basin system surface water resources in management study. Information Building Block. Part II, Vol. 2. Ministry of Works and Housing, Accra

Otto M (1998) Multivariate methods. In: Kellner R, Mermet JM, Otto M, Widmer HM (eds) Analytical chemistry. Wileye, Weinheim

Peters NE (1984) Evaluation of environmental factors affecting yields of major dissolved ions of streams in the United States. USGS Water-Supply Paper 2228 
Pinto U, Maheshwari B (2011) River health assessment in Peri-urban landscapes: an application of multivariate analysis to identify the key variables. Water Res 45:3915-3924

Pinto U, Maheshwari B, Ollerton R (2012) Analysis of long-term water quality for effective river health monitoring in peri-urban landscapes - a case study of the Hawkesbury-Nepean river system in NSW, Australia. Environ Monit Assess 185(6):4551-4569

Preda M, Cox ME (2000) Sediment-water interaction, acidity and other water quality parameters in a subtropical setting, Pimpama River, southeast Queensland. Environ Geol 39(3-4):319-329

Reghunath R, Murthy TRS, Raghavan BR (2002) The utility of multivariate statistical techniques in hydrogeochemical studies: an example from Karnataka, India. Water Res 36:2437-2442

Sangu RPS, Sharma SK (1987) An assessment of water quality of River Ganga at Garmukteshwar (Ghaziabad). Indian J Ecol 14(2):278-287

Shrestha S, Kazama F (2007) Assessment of surface water quality using multivariate statistical techniques: a case study of the Fuji river basin, Japan. Environ Model Softw 22:464-475

Simeonov V, Stratis JA, Samara C, Zachariadis G, Voutsa D, Anthemidis A (2003) Assessment of the surface water quality in Northern Greece. Water Res 37:4119-4124

Simeonova P, Simeonov V, Andreev G (2003) Environmetric analysis of the Struma River water quality. Cent Eur J Chem 2:121-126
Singh KP, Malik A, Mohan D, Sinha S (2004) Multivariate statistical techniques for the evaluation of spatial and temporal variations in water quality of Gomti River (India): a case study. Water Res 38:3980-3992

Singh KP, Malik A, Sinha S (2005) Water quality assessment and apportionment of pollution sources of Gomti river (India) using multivariate statistical techniques: a case study. Anal Chim Acta 538:355-374

UNESCAP (2000) State of the environment in Asia and the Pacific, 2000. United Nations, New York

Vega M, Pardo R, Barrado E, Deban L (1998) Assessment of seasonal and polluting effects on the quality of river water by exploratory data analysis. Water Res 32:3581-3592

WHO (2004) Guidelines for drinking-water quality, 3rd edn. WHO, Geneva

Wu ML, Wang YS, Sun CC, Wang HL, Dong JD (2009) Using chemometrics to identify water quality in Day Bay, China. Oceanologia 52:217-232

Wunderlin DA, Diaz MP, Ame MV, Pesce SF, Hued AC, Bistoni MA (2001) Pattern recognition techniques for the evaluation of spatial and temporal variations in water quality. A case study: Suquia river basin (Cordoba, Argentina). Water Res $35: 2881-2894$ 